\title{
Integrating habitat- and species-based perspectives for wetland conservation in lowland agricultural landscapes
}

\author{
Simone Guareschi ${ }^{1,2}$ (D) $\cdot$ Alex Laini $^{3} \cdot$ Pierluigi Viaroli $^{3} \cdot$ Rossano Bolpagni $^{3,4}$
}

Received: 1 May 2019 / Revised: 18 September 2019 / Accepted: 3 October 2019 /

Published online: 17 October 2019

(C) The Author(s) 2019

\begin{abstract}
Wetlands are among the most endangered ecosystems worldwide with multiple direct and indirect stressors, especially in human-altered areas like intensive agricultural landscapes. Conservation management and efforts often focus on species diversity and charismatic taxa, but scarcely consider habitats. By focusing on a complex formed by 107 permanent wetlands at 18 Natura 2000 sites in the Emilia-Romagna region (northern Italy), the patterns of habitats of conservation concern were investigated and the concordance with threatened species patterns was analysed. Wetlands were characterised in terms of morphology, connectivity, land use and management as drivers of assemblage and richness patterns of habitats. Our results showed a strong concordance between the distribution and richness patterns of both habitats and threatened taxa (birds, mammals, amphibians, reptiles, fish, invertebrates, and plants). Thus, habitats seem an effective proxy of species patterns. The variables related with perimeter, environmental heterogeneity and presence of water bodies were the most important ones associated with habitat richness patterns. The presence of aquatic systems (measured as the percentage of wetland area occupied by an aquatic surface) and their position in the hydrographic network were associated mostly with habitats distribution. Low richness wetlands (in habitat terms) were not complementary as no new habitat types were supported. The results stressed the relevance of wetlands with wide water body perimeters composed of diverse systems as being key for biodiversity conservation in a simplified agricultural matrix. Integrating habitat- and species-based perspectives seems a promising field and may provide a rapid assessment tool to acquire effective information for wetlands conservation and assessment.
\end{abstract}

Keywords Protected areas · Nature conservation - Freshwater ecosystems - Assemblage concordances $\cdot$ Biodiversity monitoring $\cdot$ Surrogates

Communicated by Frank Chambers.

Electronic supplementary material The online version of this article (https://doi.org/10.1007/s1053 1-019-01876-8) contains supplementary material, which is available to authorized users.

Simone Guareschi

S.Guareschi@lboro.ac.uk

Extended author information available on the last page of the article 


\section{Introduction}

Wetlands are critical ecosystems for the biodiversity they support and the ecosystem services they provide (De Groot et al. 2012; Junk et al. 2013). At the same time however, these diversified ecosystems suffer numerous and multiple impacts, even in the climate change context (Cížková et al. 2013; Junk et al. 2013). This is especially true for lowland agricultural landscape, where wetlands and small standing-water ecosystems are residual hotspots of local biodiversity and ecosystem functioning, despite their progressive and global disappearance (e.g. Zedler 2003; Bolpagni et al. 2019). Hence, in heavily exploited agricultural landscapes, wetlands represent unique "natural islands" in a dense anthropogenic matrix (Lastrucci et al. 2010; Bolpagni and Piotti 2016).

Measuring and monitoring biodiversity are crucial tasks for wetlands conservation and management, also for designating effective protected areas and ecological restoration plans. However, evaluating the conservation status and monitoring the biodiversity of wetlands is a complex matter. Surveying biodiversity may present certain difficulties, such as limited financial resources and/or time, and requiring considerable expertise for different components. For these reasons, surrogates, proxies or indicators, herein used as synonymous, as species surrogates (e.g. Sánchez-Fernández et al. 2006; Caro 2010) or environmental surrogates (e.g. Faith 2003; Beier and de Albuquerque 2015) have been tested or suggested in numerous geographic areas and ecosystems (for complete definitions, see Hunter Jr et al. 2016). Given the strict relationship linking terrestrial, riparian and aquatic habitats in wetlands, different kinds of indicators have been tested including plants (Rogers et al. 2012; Chamberlain and Brooks 2016), invertebrates (Kashian and Burton 2000; Ormerod et al. 2010; Guareschi et al. 2015a) and vertebrates (e.g. Frederick et al. 2009; Guareschi et al. 2015b). However, many authors have stressed contrasting findings after using surrogates or context-specific responses (e.g. Araújo et al. 2001; Lindenmayer et al. 2015; Pierson et al. 2015). To date, conservation and restoration efforts often focus on specific plants or charismatic animals (e.g. species red lists), and a limited integration between both approaches has been recorded (McAlpine et al. 2016).

In global terms, the Ramsar convention on wetlands (Ramsar Bureau 2000) designates sites of international importance (more than 2300 worldwide) following specific requisites based on animals, plants or ecological communities in general, plus specific criteria on vertebrates (fish and waterbirds) in particular. In Europe, the Natura 2000 (N2000) network represents the key tool for biodiversity conservation, following Habitats Directive 92/43/ EC (HD) and Birds Directives 79/409/EC and 2009/147/EC (BD). Nationwide, each country also identifies and selects specific local taxa or habitats of conservation concern (e.g. in Italy by Bolpagni et al. 2010; Genovesi et al. 2014).

Vegetation-based indicators have been used to assess wetland restoration and conservation priorities (Matthews et al. 2009; Benavent-González et al. 2014; Angiolini et al. 2017), by considering that several animal communities can be affected by vegetation structures/ systems (Schwab et al. 2002; Zellweger et al. 2017). In fact, vegetation plays a pivotal role in shaping physical habitats, especially in aquatic contexts where aquatic plants act as engineer species deeply modifying the colonized environments (Pierobon et al. 2010; Ribaudo et al. 2018).

For this reason, vegetation has been used in environmental legislation as a mainstay to define habitats of conservation priority (e.g. sensu HD). In the biodiversity assessment and conservation planning context, habitats are increasingly being tested for species conservation (Bunce et al. 2013), and their relevance has already been specifically stressed for 
marine (Dalleau et al. 2010) and terrestrial ecosystems (Oliver et al. 2004). Nevertheless, little is known about their roles in inland wetlands, mainly in lowland agricultural landscapes (but see an example in a Mediterranean wetland network, Angiolini et al. 2017). Indeed, the relationship between livestock, farming, irrigation and nature conservation is a critical and crucial topic, with open debate in biological conservation (Bolpagni and Piotti 2016). The need for conservation efforts in densely populated areas has been stressed by Ricketts and Imhoff (2003) in North America as being just as important as preserving pristine regions. Moreover, the relevance of agri-environment schemes and agricultural matrices for constructive biodiversity conservation has been pointed out in Europe and elsewhere (Vandermeer and Perfecto 2007; Batáry et al. 2015; Bolpagni and Piotti 2016).

In order to contribute to the biological conservation of wetlands and to provide pivotal information for protected area management and future definitions, we herein integrated habitat- and species- based perspectives to better understand the contribution of habitats (sensu HD) to wetland biodiversity in a heavily exploited agricultural landscape in northern Italy.

This work specifically aimed to study and test: (i) if European and national habitats of conservation interest (HCI hereinafter) can act as a proxy of species of conservation concern (SCC hereinafter), in both richness and composition terms; (ii) the main environmental descriptors associated with the richness and distribution of $\mathrm{HCI}$; and (iii) the role of protected areas with low HCI richness values as potential complementary sources of representativeness and conservation interest. Our hypotheses were that HCI would serve as indicators of wealth in rare and protected species (SCC), and that morphological and ecological drivers, related mainly to the morphological complexity of wetlands, could explain the observed patterns.

To address the first point, we assess whether HCI could be used as rapid tools for assessing wetland biotic integrity and biodiversity in a heavily exploited landscape, and also for their versatility as ecological surrogates, while exploring the other two topics provides applied information for wetlands management and conservation in protected area networks.

\section{Materials and methods}

\section{Study area}

This study focussed mostly on a complex formed by 107 permanent inland wetlands at 18 N2000 sites in the Emilia-Romagna region, northern Italy (Fig. 1, details available in Supplementary Material ESM1). These freshwater wetlands are located in a $~ 5600 \mathrm{~km}^{2}$ heavily exploited, lowland agricultural landscape (within the range 4-40 m a.s.l.) through the Po River plain. This area is one of the most productive in the northern Hemisphere, and it is characterised by a marked imbalance between fertilisation and the uptake capacity of crops to result in widespread water contamination by phosphorus and nitrogen (Viaroli et al. 2018). The lowland Po plain presents a temperate climate (Köppen climate classification Cfa, Peel et al. 2007), with mean annual precipitation of $\sim 700 \mathrm{~mm}$ and mean annual temperature of $13-14^{\circ} \mathrm{C}$.

Both habitats of European (EU) and national (ITA) relevance were considered to obtain the final overall HCI value (HCI codes and descriptions available in the results section, Table 1). Regarding SCC, attention was paid to the birds belonging to Annex I of the BD 


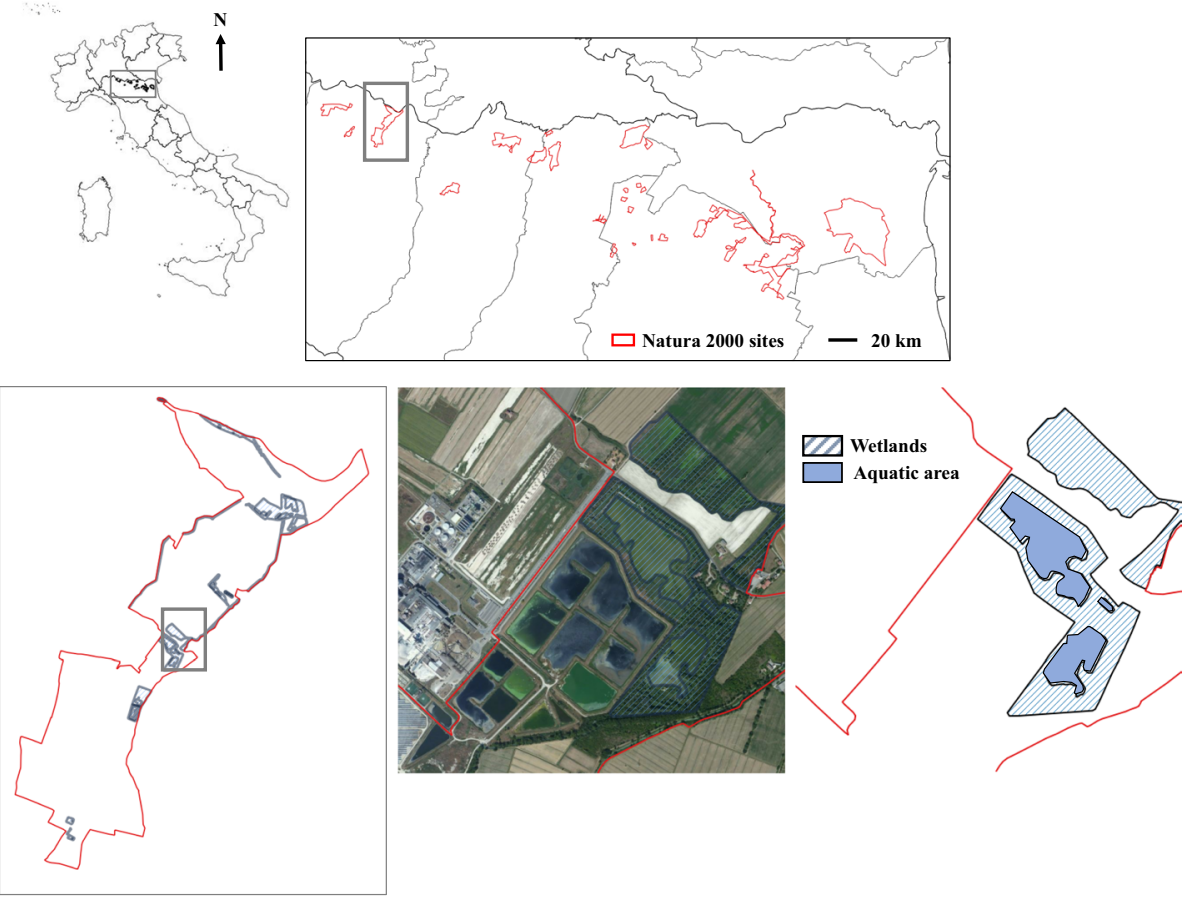

Fig. 1 Study area (Emilia Romagna region, Northern Italy) with zoom on the Natura 2000 network studied (details available in ESM1) and on the exemplificative site VT "Aree delle risorgive di Viarolo, Bacini di Torrile, Fascia golenale del Po" SCI-SPA IT4020017, showing wetland and aquatic areas

(Supplementary Material ESM2), animal taxa (mammals, amphibians, reptiles, fish, invertebrates), and the plants in Annex II of the HD (Supplementary Material ESM3).

All 107 wetlands were characterised to identify the role played by morphology, connectivity, land use and management (20 environmental variables; Table 2) to determine the patterns and richness of HCI. Data about HCI were obtained from the Emilia-Romagna Regional Habitat Map (updated in 2015), and from specific field surveys carried out in the summer and autumn of 2016 to verify the spatial patterns and local representativeness of HCI. Data on SCC were obtained from the Emilia-Romagna Region N2000 database (available at https://ambiente.regione.emilia-romagna.it/it/parchi-natura2000/rete-natur a-2000/habitat-e-specie-di-interesse-europeo).

\section{Statistical analysis}

Firstly, the relationships among the abundance of national, European and total HCI were tested by Pearson correlations. Then, the potential concordance patterns of HCI and SCC were analysed in two complementary ways: richness and composition patterns.

Linear regressions and correlations were used to investigate the relationship between the overall richness patterns of habitats and taxa of conservation interest. The latter was possible by considering the general set of the N2000 sites $(n=18)$, which comprise 120 wetlands as data were available on a protected area scale (N2000, list and names available in ESM1), but not for every single water body. 


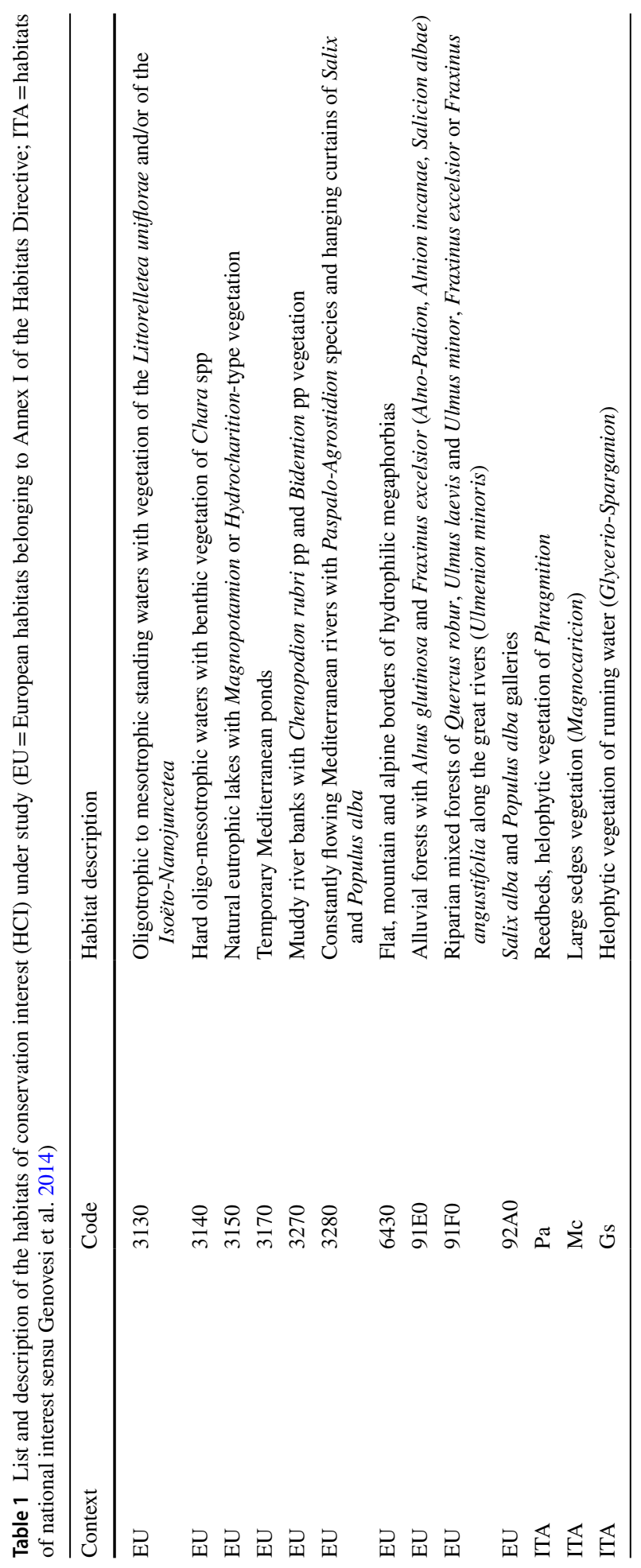




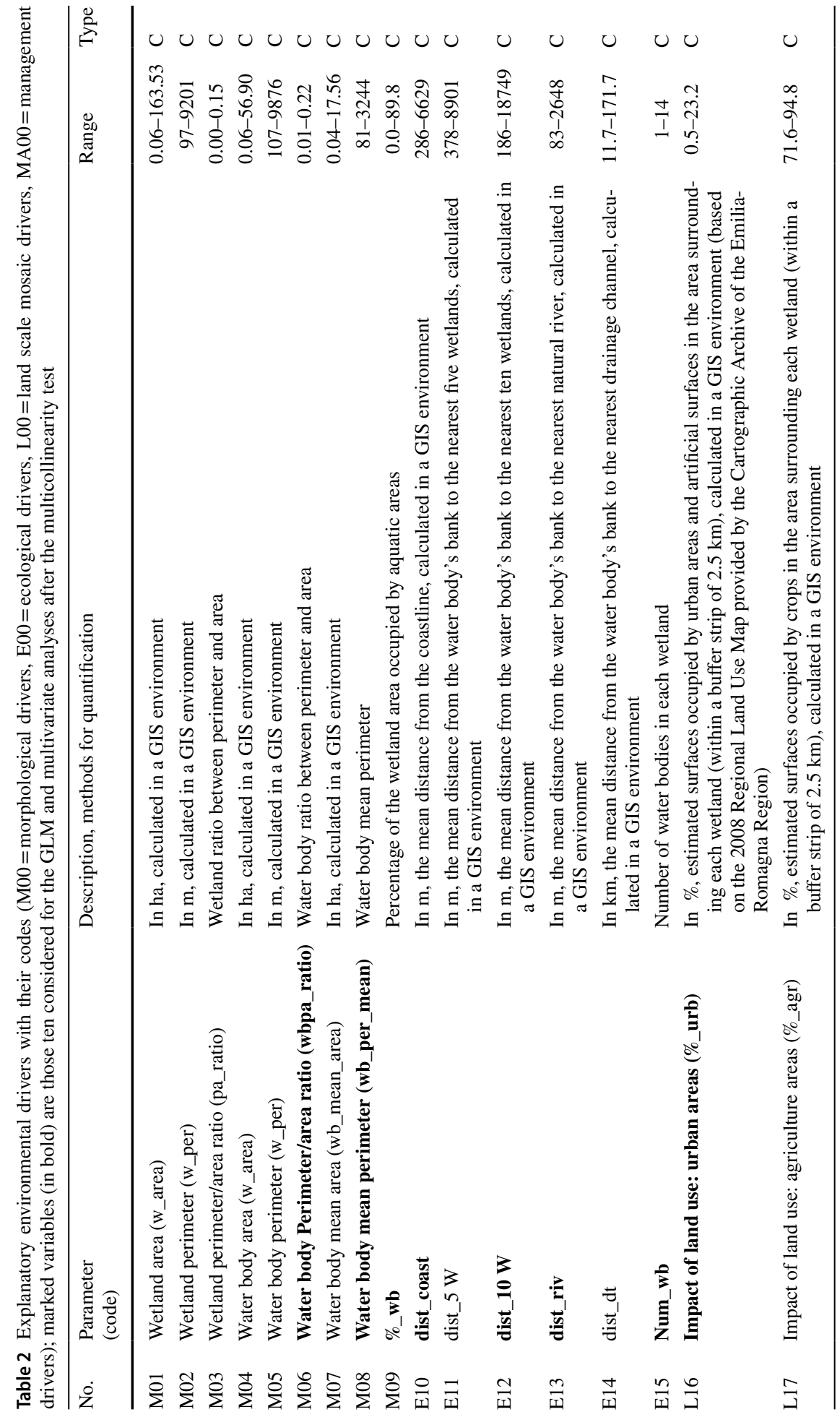




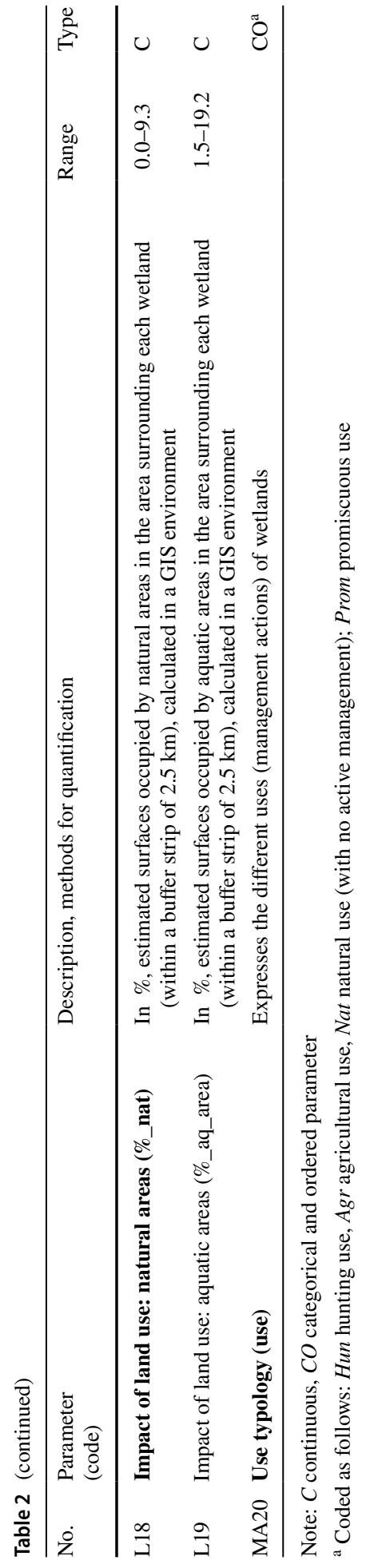


Weighted classical multidimensional scaling (the "wcmdscale" function in vegan, also known as a weighted principal coordinates analysis) was used to summarise the composition patterns of HCI and SCC on the N2000 protected site scale $(n=18)$. Analyses were performed with a matrix based on presence-absence data, using the Jaccard Index (Legendre and Anderson 1999). A Procrustean analysis, accompanied by a permutation test $(n=9999)$, was applied to evaluate the degree and significance of the concordance between the ordinations obtained by respectively considering HCI and SCC. A Procrustean rotation analysis is regarded as a robust method for concordance analyses (Peres-Neto and Jackson 2001) and is frequently used to study ecosystem and community patterns (e.g. Virtanen et al. 2009; Guareschi et al. 2015b; Slimani et al. 2019). The statistic obtained is a Procrustes correlation $r$ that derives from the symmetric Procrustes residual $m^{2}\left(r=\sqrt{ } 1-m^{2}\right)$.

Having investigated the concordance patterns, the study focussed on the environmental variables associated with HCI assemblages and richness. Despite the biodiversity relevance of temporary wetlands and watercourses (e.g. Zacharias and Zamparas 2010), for the subsequent statistical analysis, attention was paid to the main pool of the 107 permanent systems at the 18 N2000 to manage a homogenous dataset. This allowed tests to be done with the complete list of environmental variables, including those related with water surface.

To avoid any collinearity among the 20 environmental drivers, a selection based on variance inflation factor (VIF with "th value" fixed =2) was used to reduce the number of variables in the modelling procedure (Naimi et al. 2014).

Generalised linear models (GLM; Crawley 1993) were applied to investigate which environmental descriptors were associated with the richness of the HCI in the studied area. GLM analyses were carried out by considering a Poisson error distribution and a log-link function. Outliers, overdispersion and independence of residuals (Shapiro-Wilk test) were assessed following Fox and Weisberg (2011) and Zuur et al. (2009).

Non-metric multidimensional scaling (NMDS with function 'metaMDS') was used to assess the main patterns in the HCI assemblage structure. The analysis was done with a habitat matrix based on presence-absence data, using the Jaccard Index. The threshold at which ordination was not considered reliable was set at 0.20 . Linear fittings, using the vegan function 'envfit', were performed between the selected environmental variables and the ordination outputs to identify the environmental factors associated with HCI distribution. The significance of the fitted variables was assessed by a permutation procedure (9999 permutations).

Finally, low richness areas $(\mathrm{HCI} \leq 2)$ were explored to assess their role in habitat representativeness and were directly compared with richer areas $(\mathrm{HCI}>2)$. All the analyses were performed with the R 3.5.1 software of the R statistical environment (R Core Team 2018) with packages "vegan" (Oksanen et al. 2018), "psych" (Revelle 2018), "usdm" (Naimi et al. 2014) and "car" (Fox and Weisberg 2011).

\section{Results}

\section{Concordances between species and habitats}

Fifty-nine species of conservation concern and $13 \mathrm{HCI}$ (EU habitats $\mathrm{n}=10$, and national relevance habitats $n=3$; see Table 1) were detected in the 18 N2000 sites under study. SCC were represented mostly by waterbirds $(n=45,78 \%)$. The most widespread species detected in all the sites were Alcedo atthis, Egretta garzetta, Ixobrychus minutus, and 
Nycticorax nycticorax. By contrast, only a few fish $(\mathrm{n}=4$; Barbus plebejius, Chondrostoma soetta, Cobitis bilineata, and Protochondrostoma genei), invertebrates $(\mathrm{n}=3$; Austropotamobius pallipes, Graphoderus bilineatus and Lycaena dispar), amphibians ( $\mathrm{n}=2$; Rana latastei, and Triturus carnifex), mammalians ( $\mathrm{n}=2$; Myotis bechsteini, and M. myotis), reptiles ( $\mathrm{n}=1$; Emys orbicularis), and plants $(\mathrm{n}=1$; Marsilea quadrifolia) were represented. Waterbirds also represented the commonest SCC group in each single protected site. The N2000 site Biotopi e Ripristini di Ambientali di Medicina e Molinella (Bologna Province, coded as MM in ESM1) presented both the biggest number of HCI (11) and SCC (49).

The habitat of national concern "Pa" (reed-beds, riparian formations of Phragmition) and EU habitat code 3270 (Rivers with muddy banks with vegetation of Chenopodion rubri pp and Bidention pp) were the commonest habitats, and were present in 99 and 87 permanent wetlands, respectively, and in 17 of the 18 N2000 protected sites (Fig. 2).

The correlation analysis stressed a very strong relationship (Pearson correlation $r=0.96$, and Spearman rank correlation $r=0.97$, both $\mathrm{p}<0.01, \mathrm{n}=107$, Fig. 3a) between EU habitats and the overall $\mathrm{HCI}$ value $(\mathrm{HCI}=\mathrm{EU}+\mathrm{ITA})$. Lower values were obtained between the EU and national habitats (Spearman rank $\mathrm{r}=0.63, \mathrm{p}<0.01$ ). The same correlation values were obtained when considering the entire pool of 120 wetlands.

A linear model between species and habitats of conservation concern (HCI) stressed a strong relationship between their richness patterns at N2000 scale (adjusted $\mathrm{R}$-squared $=0.693, \mathrm{p}<0.0001, \mathrm{n}=18$, Fig. 3b). The same findings were obtained with the correlation analysis (Pearson $\mathrm{r}=0.84, \mathrm{p}<0.001$ ). This was also confirmed by testing the mean number of HCI when considering the 107 wetlands (adjusted R-squared $=0.384$, $\mathrm{p}=0.0036, \mathrm{n}=107)$.

According to the protest analysis, the assemblage of SCC and HCI was significantly concordant across the $\mathrm{N} 2000$ protected sites $\left(\mathrm{r}\right.$ value $=0.758, \mathrm{~m}^{2}$ statistic $=0.425, p$ value $=0.0001, \mathrm{n}=18$ ). The strong correlation detected between SCC and HCI in both

Habitats of Conservation Interest $(\mathrm{HCl})$

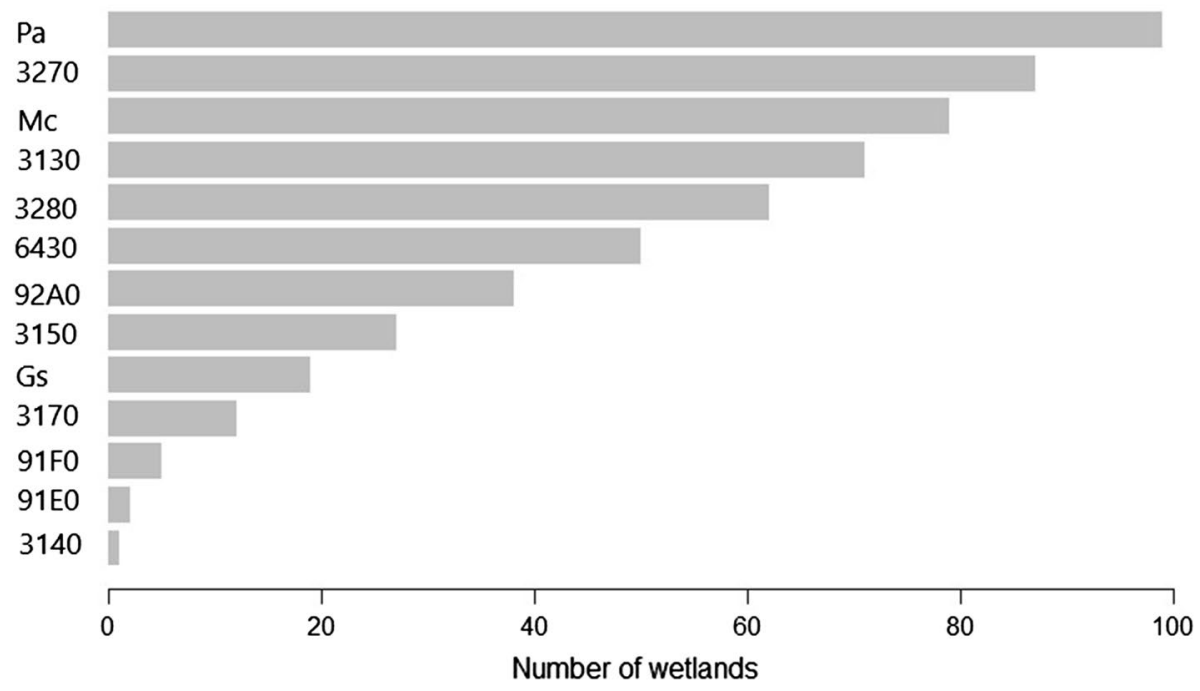

Fig. 2 Abundance (number of wetlands) of each habitat of conservation interest (HCI) detected in permanent systems $(n=107$, code details available in Table 1$)$ 
(A)
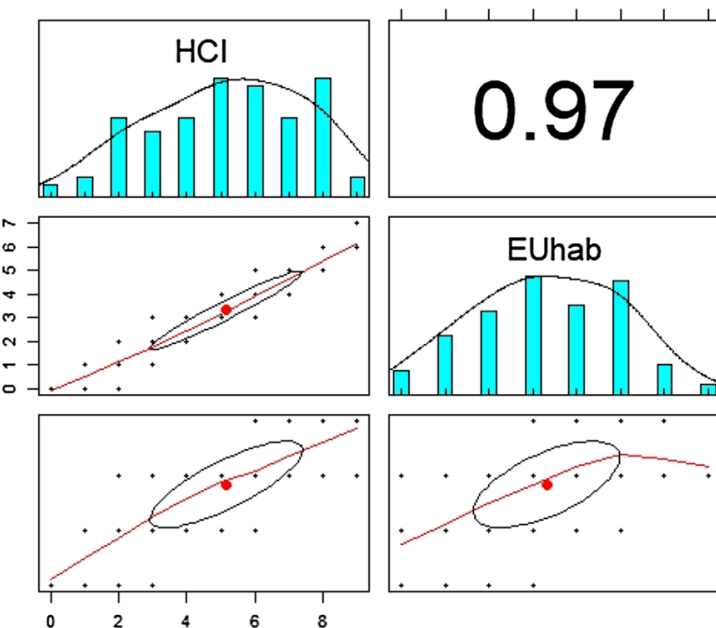
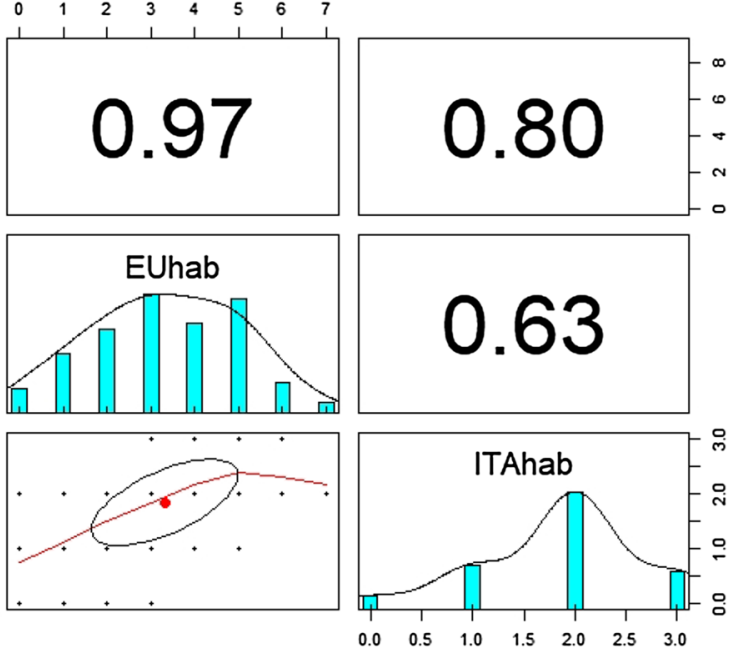

(B)

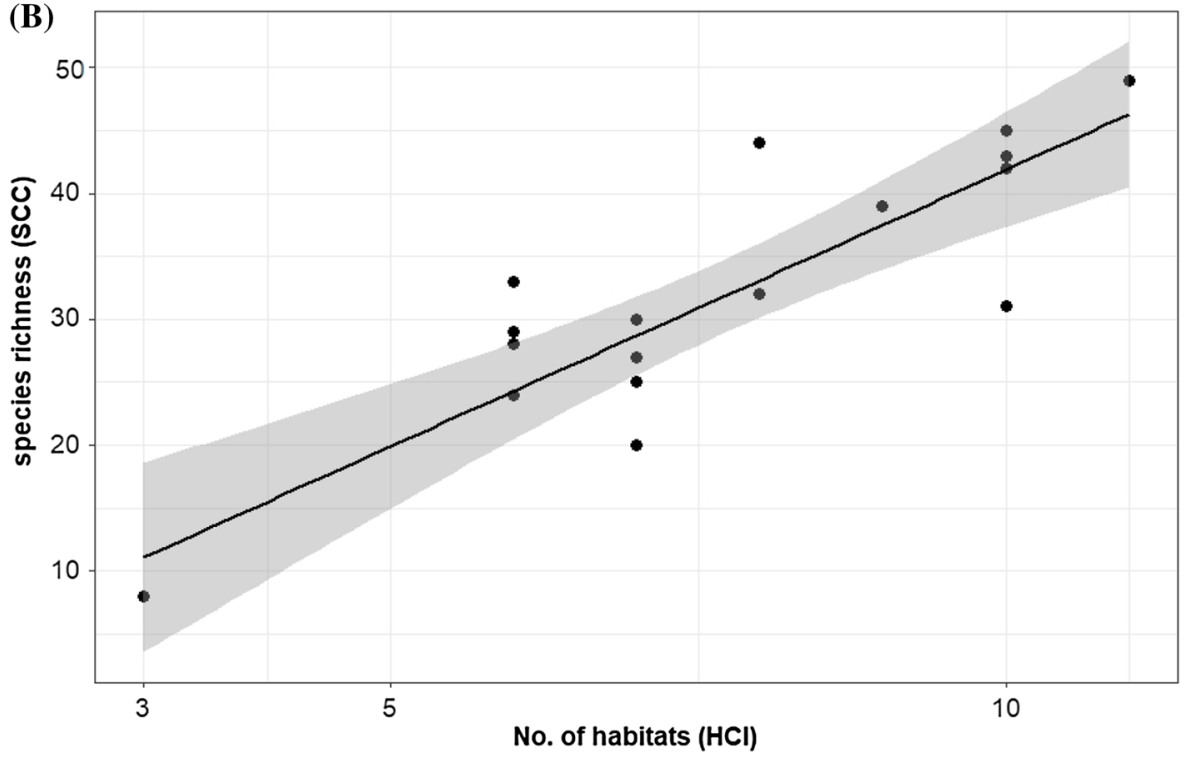

Fig. 3 a Correlation patterns (Spearman rank correlation and $\mathrm{p}<0.01)$ among European (EUhab), national (ITAhab) and total habitats (HCI), upper panel; b Linear regression plot between HCI and species of conservation interest (SCC richness $=4.395 \mathrm{HCI}-2.086$; lower panel)

terms of richness and distribution patterns (aim 1) allowed the multivariate and GLM analyses for HCI to be applied and to fully pursue the other research aims (2-3).

\section{Richness and composition patterns of $\mathrm{HCl}$ and environmental variables}

The GLM analysis explained $60.2 \%$ of HCI richness deviance $(n=107$ wetlands, $\mathrm{AIC}=421.7$ ) with the considered set of environmental variables (Table 3 ). The water 
Table 3 GLM results relating the HCI richness and explanatory environmental drivers (see Table 2 for the complete variable code details)

\begin{tabular}{lrll}
\hline Environmental drivers & \multicolumn{1}{c}{ Estimate } & Std. error & p-value \\
\hline Intercept & $1.81 \mathrm{e}+00$ & $2.77 \mathrm{e}-01$ & $6.13 \mathrm{e}-11^{* * *}$ \\
wbpa_ratio & $-2.17 \mathrm{e}+00$ & $1.39 \mathrm{e}+00$ & 0.1182 \\
wb_per_mean & $2.33 \mathrm{e}-04$ & $9.41 \mathrm{e}-05$ & $0.0133^{*}$ \\
\%_wb & $-1.04 \mathrm{e}-02$ & $2.57 \mathrm{e}-03$ & $5.41 \mathrm{e}-05^{* * *}$ \\
dist_10 W & $4.46 \mathrm{e}-06$ & $2.83 \mathrm{e}-05$ & 0.8748 \\
dist_riv & $4.70 \mathrm{e}-06$ & $1.30 \mathrm{e}-05$ & 0.7171 \\
dist_coast & $-9.91 \mathrm{e}-07$ & $1.49 \mathrm{e}-06$ & 0.5061 \\
num_wb & $4.07 \mathrm{e}-02$ & $1.61 \mathrm{e}-02$ & $0.0117^{*}$ \\
\%_urb & $2.84 \mathrm{e}-04$ & $1.33 \mathrm{e}-02$ & 0.983 \\
$\%$ nat & $1.15 \mathrm{e}-02$ & $2.16 \mathrm{e}-02$ & 0.5944 \\
use & $1.30 \mathrm{e}-03$ & $6.92 \mathrm{e}-02$ & 0.985 \\
\hline
\end{tabular}

$* * * \mathrm{p}<0.001 ; * * \mathrm{p}<0.01 ; * \mathrm{p}<0.05$

body mean perimeter (wb_per_mean), the percentage of wetland area occupied by aquatic areas (\%_wb, with a negative sign), and the number of water bodies in each wetland (num_wb) were the significant environmental predictors associated with the HCI richness patterns (complete details in Table 3).

For HCI assemblage, the best two-dimensional solution ordination presented a final stress value of 0.126 (Fig. 4). Assemblage was principally affected again by the percentage of wetland area occupied by aquatic areas (\%_wb) and by the hydrographic networks in terms of the distance and connectivity from other aquatic systems (dist_10 W, dist_riv). All the most significant environmental variables presented similar $\mathrm{r}^{2}$ values $(0.10-0.13 ; \mathrm{p}<0.01)$ (see Table 4$)$.

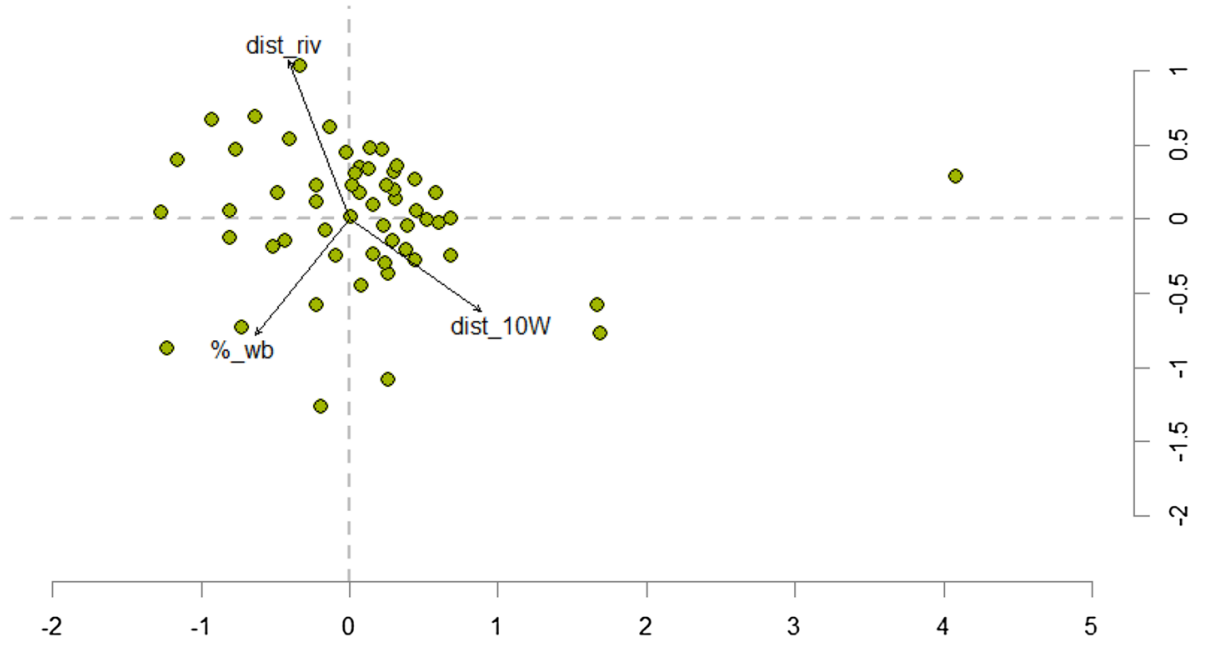

Fig. 4 NMDS plots (first two dimensions displayed, stress value $=0.126$ ) based on the HCI presenceabsence matrix (permanent wetlands). Only the variables significant at $\mathrm{p}<0.01$ are displayed (see Table 2 for details of variable codes and Table 4 for the complete results) 
Table 4 Correlations of the explanatory environmental drivers with the NMDS ordinations of HCI. The significance of the correlation based on the envfit function (9999 permutations)

\begin{tabular}{lrrll}
\hline Environmental drivers & NMDS1 & NMDS2 & $\mathrm{r}^{2}$ & $\operatorname{Pr}(>\mathrm{r})$ \\
\hline wbpa_ratio & -0.65218 & -0.75806 & 0.0529 & 0.083 \\
wb_per_mean & 0.66588 & 0.74606 & 0.0579 & 0.058 \\
\%_wb & -0.63822 & -0.76986 & 0.1013 & $0.005^{* *}$ \\
dist_10 W & 0.83148 & -0.55555 & 0.1149 & $0.004^{* *}$ \\
dist_riv & -0.35384 & 0.93531 & 0.1291 & $0.002^{* *}$ \\
dist_coast & -0.84390 & -0.53650 & 0.0694 & $0.027^{*}$ \\
num_wb & 0.47417 & 0.88043 & 0.0737 & $0.024^{*}$ \\
\%_urb & -0.06284 & -0.99802 & 0.0041 & 0.785 \\
\%_nat & 0.96952 & 0.24499 & 0.0662 & $0.036^{*}$ \\
use & 0.11015 & -0.99392 & 0.0094 & 0.630 \\
\hline
\end{tabular}

See Table 2 for the complete variable code details. The goodness-of-fit statistic is the squared correlation coefficient $\left(\mathrm{r}^{2}\right)$

$* * \mathrm{p}<0.01 ; * \mathrm{p}<0.05$

\section{Comparing high and low $\mathrm{HCl}$ richness wetlands}

Ninety of the 107 wetlands presented more than two HCIs (mean $=5.8$, $\max =9.0$ ), while 17 wetlands were classified as poor in habitat richness terms $(\mathrm{HCI} \leq 2)$. In both rich and poor wetlands, the national habitat "Pa" (Phragmition) and the EU habitat code 3270 (Chenopodion rubri pp and Bidention pp vegetation) were the most widespread in abundance and percentage terms, and "Pa" was particularly common in both cases (see Table 5 for details). EU habitats code 3140 (Hard oligo-mesotrophic waters with benthic vegetation of Chara spp.) and 91E0 (Alluvial forests with Alnus glutinosa and Fraxinus excelsior) were the rarest HCI as they appeared in only one (BB) and two (BO, and PT) protected sites, respectively. Accordingly, they were detected only in the richest group. The low richness group did not provide any exclusive or rare HCI (Table 5). Finally, even the few non-perennial wetlands excluded from the other statistical analysis did not provide any complementary or rare habitats (data not shown).

\section{Discussion}

\section{Conservation in a heavily exploited environmental matrix}

According to previous studies, a strong concordance among taxonomic groups should be indicated by high $\mathrm{r}$ values (e.g. $>0.7$, Heino 2010, and references within). Here, following our findings, the HCI patterns seemed to act as a good multipurpose proxy of threatened taxonomic species diversity (SCC) in richness and distribution terms, as we initially hypothesised. However, it should be taken into account that most of the SCC considered herein were waterbird species, whereas the other taxonomic groups were poorly represented. Based on this, further research is recommended to better understand and confirm the concordance patterns of HCI with other animal and/or plant species (e.g. multitaxon datasets), and ideally not only from a taxonomic point of view (multi perspective approach). 


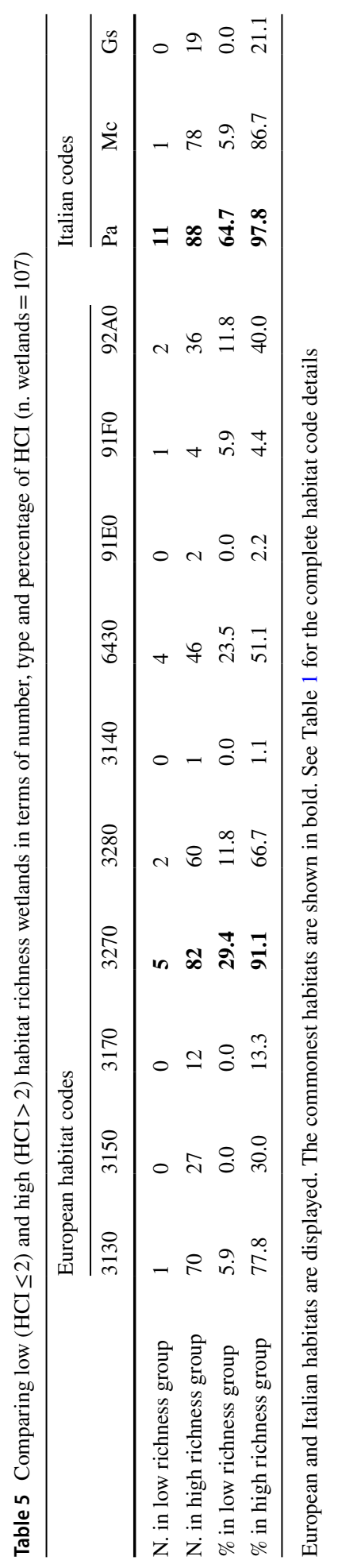


The overall value of the $10 \mathrm{EU}$ habitats of conservation interest (of a total value of 13 $\mathrm{HCI}$ ) is not particularly high as it represents around $8 \%$ of all EU habitats that have been recognised for the Italian Continental Region $(n=83$, Genovesi et al. 2014), but represents the bulk of the recorded HCI values (77\%). Conservation in highly human-exploited ecosystems is a truly hard challenge for the different stakeholders involved, like conservationists, natural resource managers, environmental agencies, farmers, and society as a whole. The protected sites in similar matrices suffer multiple pressures, which imply the risk of biodiversity loss and trivial communities and, due to their geographical location, they can be greatly demanded by the general public (e.g. recreational services or improper uses). Current and future anthropogenic pressures have been demonstrated to have direct implications for protected areas and biodiversity conservation. In fact, the distance between protected areas and cities is predicted to dramatically reduce in some regions (McDonald et al. 2008). Moreover, the importance of the human footprint in shaping the distribution of numerous terrestrial and aquatic invaders have also been stressed (Gallardo et al. 2015), and heavily exploited environmental matrices like lowland agricultural and urban landscapes usually attain high levels of invasion (e.g. Chytrý et al. 2009). These issues represent challenges and threats to which conservation planning should respond (e.g. management and monitoring of reserves, Margules and Pressey 2000).

\section{Richness and distribution $\mathrm{HCl}$ patterns}

The richness model explained a large amount of deviance with the considered environmental predictors. It would appear that at least some variables were significantly associated with the HCI patterns in the studied sites.

On the one hand, high values of the mean perimeter of water bodies within a given wetland (wb_per_mean) and the presence of diverse waterbodies (in number terms) were positively associated with the highest HCI richness values. Both variables can indicate the extent of the riparian, and therefore ecotonal, zones in each wetland and, consequently, overall environmental (i.e. morphological) heterogeneity. The relevance of habitat heterogeneity has already been stressed by Shi et al. (2010) as being important for vascular plant species richness in Chinese wetlands, and by Báldi (2008) for invertebrate richness in Hungarian protected areas, but it is also a matter of some other contrasting findings (e.g. Palmer et al. 2010). Aquatic-terrestrial ecotones have been recognised as crucial zones because they act as natural filters, a source of organic carbon, and as connection lines for energy and materials fluxes (Décamps and Naiman 1990; Naiman et al. 2002).

On the other hand, the percentage of wetland area occupied by just aquatic areas was negatively associated with the HCI richness patterns. This should not clash with what has been discussed above. In fact, a massive extension of water surface can occupy a large wetland area without providing specific habitat and wide environmental heterogeneity. Accordingly, it would seem that numerous and diverse, but not extended, aquatic systems (i.e. water bodies) would benefit HCI richness by promoting heterogeneous riparian and ecotonal zones. This is indeed true for heavily exploited watersheds where the quality level of surface waters is expected to be generally poor. Similar evidence has been collected in a comparable system of wetlands located along the Oglio River (Lombardy region), a left tributary of the Po River (Bolpagni et al. 2013; Bolpagni and Piotti 2015, 2016). These authors verified that aquatic and amphibian plant diversity was driven more by site features (natural vs. artificial), and by their morphological complexity (i.e. presence of wide ecotones) rather than by hydrology. 
HCI distribution was associated with only a few significant predictors, which were not particularly strong in $\mathrm{r}^{2}$ terms, but differed from those associated with HCI richness, except for the variable "percentage of wetland area occupied by aquatic areas". In this case, this predictor was mostly coupled with the descriptors related to the hydrographic network, such as distance to other aquatic systems (i.e. rivers and wetlands).

Overall, the traditional variables, widely considered in conservation planning like wetland area or wetland perimeter, were not the first stressed predictors in both cases (richness and distribution) despite some indirect relations with some significant variables being observed. This seems to underline the relevance of other variables (not just the commonest ones) associated with HCI patterns, at least in the considered highly exploited environmental matrix.

On the considered regional scale, the wetlands with low habitat richness seem quite trivial as they never bring new or complementary HCI. However, they still play a relevant role in habitat redundancy and resilience by ensuring the presence of habitats of interest in the study area.

\section{Conservation implications and final remarks}

In wetland biodiversity and monitoring context, habitats (in richness and distribution terms) can be considered a proxy for species of conservation interest (as a strictly taxonomic measure). Furthermore, HCI help to improve our capability to understand the real and/or potential conservation value of small natural features, like small wetlands in agricultural landscapes (Hunter Jr 2017; Bolpagni et al. 2019). Accordingly, they could be used as rapid tools for assessing the biotic integrity of wetlands and should also be tested under other geographical and environmental conditions.

Significantly, only three invertebrate taxa are cited as SCC in the 18 studied protected sites, namely L. dispar (Lepidoptera), G. bilineatus (Coleoptera), and A. pallipes (Decapoda), along with one aquatic fern (M. quadrofolia, Marsileaceae). This is probably because there are only a few invertebrates (especially aquatic insects) and macrophytes, comprising non-vascular species, included on official Conservationist Lists (e.g. HD, Annex II). In fact, the European Union's conservation efforts are taxonomically biased towards vertebrates (Mammides 2019) which testifies that more research and efforts on non-target (e.g. invertebrates) and non-charismatic taxa is needed (Filz et al. 2013; Guareschi et al. 2015c; Habel et al. 2019). Specifically, periodic monitoring of these rare taxa is recommended (e.g. population persistence). Similarly, a recent ecological systematic review of the ecosystem value of small standing-water ecosystems, Bolpagni et al. (2019), verified the existence of clear narrative trends and wide knowledge gaps across geographical areas, biological components and target issues (e.g. competition, environmental drivers, human drivers).

Our research is an ambitious study into a lowland matrix exploited for agriculture and impacted by urbanization that provides useful information for its biodiversity conservation. Overall, the use of HCI as a rapid assessment tool may assist environmental managers and conservationists with limited resources. This is especially true considering that data on the presence of HCI are already available and freely accessible (at least considering the EU N2000 network, see Bunce et al. 2013). If not, HCI data seem easily achievable as their detection and effective monitoring during fieldwork is time- and cost-saving compared to in-depth taxonomic efforts and specific surveys for numerous taxa (e.g. Gigante et al. 2016). Integrating habitat- and species- based perspectives seems a promising field that 
may provide a rapid assessment tool to acquire effective information for wetlands management and conservation.

Acknowledgements SG was partially supported by a Royal Society-Newton International Fellowship (NIF) R1\180346) at Loughborough University (UK). RB was supported by an Emilia-Romagna Region Fellowship as part of the Project "Censimento e definizione dei processi evolutivi delle zone umide presenti nella Regione Emilia-Romagna, in particolare nei territori rientranti nei siti della rete Natura 2000 ed ubicati esternamente alle Aree protette" (CIG 67745431BD). Special thanks go to Maria Carla Cera, Francesco Besio, and Enzo Valbonesi (Emilia-Romagna Region) for their support and assistance in carrying out the project. The authors are grateful also to Mariano Bresciani (Institute for electromagnetic sensing of the environment, IREA-CNR) and Ilaria Cazzaniga (University of Milano-Bicocca) for help in defining water body areas, and to Monica Palazzini, Marco Pattuelli, and Stefano Bassi (Emilia-Romagna Region) for the fruitful discussion on habitats and conservation issues. Thanks go to Helen Warburton (HyA services) for checking the English grammar.

\section{Compliance with ethical standards}

Conflict of interest No potential conflict of interest is reported by the authors.

Open Access This article is distributed under the terms of the Creative Commons Attribution 4.0 International License (http://creativecommons.org/licenses/by/4.0/), which permits unrestricted use, distribution, and reproduction in any medium, provided you give appropriate credit to the original author(s) and the source, provide a link to the Creative Commons license, and indicate if changes were made.

\section{References}

Angiolini C, Viciani D, Bonari G, Lastrucci L (2017) Habitat conservation prioritization: a floristic approach applied to a Mediterranean wetland network. Plant Biosyst 151:598-612. https://doi. org/10.1080/11263504.2016.1187678

Araújo MB, Humphries CJ, Densham PJ, Lampinen R, Hagemeijer WJM, Mitchell-Jones AJ, Gasc JP (2001) Would environmental diversity be a good surrogate for species diversity? Ecography 24:103110. https://doi.org/10.1034/j.1600-0587.2001.240112.x

Báldi A (2008) Habitat heterogeneity overrides the species-area relationship. J Biogeogr 35:675-681. https ://doi.org/10.1111/j.1365-2699.2007.01825.x

Batáry P, Dicks LV, Kleijn D, Sutherland WJ (2015) The role of agri-environment schemes in conservation and environmental management. Conserv Biol 29:1006-1016. https://doi.org/10.1111/cobi.12536

Beier P, de Albuquerque FS (2015) Environmental diversity as a surrogate for species representation. Conserv Biol 29:1401-1410. https://doi.org/10.1111/cobi.12495

Benavent-González A, Lumbreras A, Molina JA (2014) Plant communities as a tool for setting priorities in biodiversity conservation: a novel approach to Iberian aquatic vegetation. Biodivers Conserv 23:21352154. https://doi.org/10.1007/s10531-014-0709-3

Bolpagni R, Piotti A (2015) Hydro-hygrophilous vegetation diversity and distribution patterns in riverine wetlands in an agricultural landscape: a case study from the Oglio River (Po Plain, Northern Italy). Phytocoenologia 45:69-84. https://doi.org/10.1127/0340-269X/2014/0044

Bolpagni R, Piotti A (2016) The importance of being natural in a human-altered riverscape: role of wetland type in supporting habitat heterogeneity and the functional diversity of vegetation. Aquat Conserv Mar Freshw Ecosys 26:1168-1183. https://doi.org/10.1002/aqc.2604

Bolpagni R, Azzoni R, Spotorno C, Tomaselli M, Viaroli P (2010) Analisi del patrimonio floristico-vegetazionale idro-igrofilo della Regione Emilia-Romagna. Schede descrittive degli habitat acquatici e igrofili. Università di Parma, Dipartimento di Bioscienze; Regione Emilia-Romagna, Bologna (Technical Report in Italian)

Bolpagni R, Bartoli M, Viaroli P (2013) Species and functional plant diversity in a heavily impacted riverscape: implications for threatened hydro-hygrophilous flora conservation. Limnologica 43:230-238. https://doi.org/10.1016/j.limno.2012.11.001

Bolpagni R, Poikane S, Laini A, Bagella S, Bartoli M, Cantonati M (2019) Ecological and conservation value of small standing-water ecosystems: a systematic review of current knowledge and future challenges. Water 11:402 
Bunce RGH, Bogers MMB, Evans D, Halada L, Jongman RHG, Mucher CA, Bauch B, De Blust G, Parr TW, Olsvig-Whittaker L (2013) The significance of habitats as indicators of biodiversity and their links to species. Ecol Ind 33:19-25. https://doi.org/10.1016/j.ecolind.2012.07.014

Caro T (2010) Conservation by proxy. Indicator, umbrella, keystone, flagship, and other surrogate species. Island Press, Washington, DC

Chamberlain SJ, Brooks RP (2016) Testing a rapid Floristic Quality Index on headwater wetlands in central Pennsylvania, USA. Ecol Indic 60:1142-1149. https://doi.org/10.1016/j.ecolind.2015.09.004

Chytrý M, Pyšek P, Wild J, Pino J, Maskell LC, Vilà M (2009) European map of alien plant invasions based on the quantitative assessment across habitats. Divers Distrib 15:98-107. https://doi.org/10.1 111/j.1472-4642.2008.00515.x

Cížková H, Kvet J, Comín FA, Laiho R, Pokorný J, Pithart D (2013) Actual state of European wetlands and their possible future in the context of global climate change. Aquat Sci 75:3-26. https://doi. org/10.1007/s00027-011-0233-4

Crawley MJ (1993) GLM for ecologists. Blackwell Science, Oxford

Dalleau M, Andréfouët S, Wabnitz CC, Payri C, Wantiez L, Pichon M, Friedman K, Vigliola L, Benzoni F (2010) Use of habitats as surrogates of biodiversity for efficient coral reef conservation planning in Pacific Ocean islands. Conserv Biol 24:541-552. https://doi.org/10.111 1/j.1523-1739.2009.01394.x

De Groot R, Brander L, Van Der Ploeg S, Costanza R, Bernard F, Braat L, Christie M, Crossman N, Ghermandi A, Hein L et al (2012) Global estimates of the value of ecosystems and their services in monetary units. Ecosyst Serv 1:50-61. https://doi.org/10.1016/j.ecoser.2012.07.005

Décamps H, Naiman RJ (eds) (1990) The ecology and management of aquatic-terrestrial ecotones, 4th edn. CRC Press, Boca Raton

Faith DP (2003) Environmental diversity (ED) as surrogate information for species-level biodiversity. Ecography 26:374-379. https://doi.org/10.1034/j.1600-0587.2003.03300.x

Filz KJ, Engler JO, Stoffels J, Weitzel M, Schmitt T (2013) Missing the target? A critical view on butterfly conservation efforts on calcareous grasslands in south-western Germany. Biodivers Conserv 22:2223-2241. https://doi.org/10.1007/s10531-012-0413-0

Fox J, Weisberg S (2011) An R companion to applied regression, 2nd edn. Sage, Thousand Oaks, CA

Frederick P, Gawlik DE, Ogden JC, Cook MI, Lusk M (2009) The White Ibis and Wood Stork as indicators for restoration of the everglades ecosystem. Ecol Indic 9:83-95. https://doi.org/10.1016/j.ecoli nd.2008.10.012

Gallardo B, Zieritz A, Aldridge DC (2015) The importance of the human footprint in shaping the global distribution of terrestrial, freshwater and marine invaders. PloS ONE 10:e0125801. https://doi. org/10.1371/journal.pone.0125801

Genovesi P, Angelini P, Bianchi E, Dupré E, Ercole S, Giacanelli V, Ronchi F, Stoch F (2014) Specie e habitat di interesse comunitario in Italia: distribuzione, stato di conservazione e trend. ISPRA, Serie Rapporti, 194/2014 (Report in Italian)

Gigante D, Attorre F, Venanzoni R, Acosta A, Agrillo E, Aleffi M, Alessi N, Allegrezza M, Angelini P, Angiolini C et al (2016) A methodological protocol for Annex I Habitats monitoring: the contribution of Vegetation science. Plant Sociol 53:77-87. https://doi.org/10.7338/pls2016532/06

Guareschi S, Velasco J, Sánchez-Fernández D, Picazo F, Carbonell JA, Bruno D, Abellán P, Millán A (2015a) Interés de conservación de los humedales Ramsar de España peninsular a través de sus comunidades de coleópteros acuáticos. Electronic Monograph, Sociedad Entomologica Aragonesa, vol 7

Guareschi S, Abellán P, Laini A, Green AJ, Sánchez-Zapata JA, Velasco J, Millán A (2015b) Crosstaxon congruence in wetlands: assessing the value of waterbirds as surrogates of macroinvertebrate biodiversity in Mediterranean Ramsar sites. Ecol Indic 49:204-215. https://doi.org/10.1016/j.ecoli nd.2014.10.012

Guareschi S, Bilton DT, Velasco J, Millán A, Abellán P (2015c) How well do protected area networks support taxonomic and functional diversity in non-target taxa? The case of Iberian freshwaters. Biol Conserv 187:134-144. https://doi.org/10.1016/j.biocon.2015.04.018

Habel JC, Samways MJ, Schmitt T (2019) Mitigating the precipitous decline of terrestrial European insects: requirements for a new strategy. Biodivers Conserv 28:1343-1360. https://doi.org/10.1007/ s10531-019-01741-8

Heino J (2010) Are indicator groups and cross-taxon congruence useful for predicting biodiversity in aquatic ecosystems? Ecol Indic 10:112-117. https://doi.org/10.1016/j.ecolind.2009.04.013

Hunter ML Jr (2017) Conserving small natural features with large ecological roles: an introduction and definition. Biol Conserv 211:1-2. https://doi.org/10.1016/j.biocon.2016.12.019 
Hunter ML Jr, Westgate M, Barton P, Calhoun A, Pierson J, Tulloch A, Beger M, Branquinho C, Caro T, Gross J et al (2016) Two roles for ecological surrogacy: indicator surrogates and management surrogates. Ecol Indic 63:121-125. https://doi.org/10.1016/j.ecolind.2015.11.049

Junk WJ, An S, Finlayson CM, Gopal B, Květ J, Mitchell SA, Mitsch WJ, Robarts RD (2013) Current state of knowledge regarding the world's wetlands and their future under global climate change: a synthesis. Aquat Sci 75:151-167. https://doi.org/10.1007/s00027-012-0278-z

Kashian DR, Burton TM (2000) A comparison of macroinvertebrates of two Great Lakes coastal wetlands: testing potential metrics for an index of ecological integrity. J Great Lakes Res 26:460-481. https://doi. org/10.1016/S0380-1330(00)70708-8

Lastrucci L, Landi M, Angiolini C (2010) Vegetation analysis on wetlands in a Tuscan agricultural landscape (central Italy). Biologia 65:54-68. https://doi.org/10.2478/s11756-009-0213-5

Legendre P, Anderson MJ (1999) Distance-based redundancy analysis: testing multispecies responses in multifactorial ecological experiments. Ecol Monogr 69:1-24. https://doi.org/10.1890/00129615(1999)069\%5b0001:DBRATM\%5d2.0.CO;2

Lindenmayer D, Pierson J, Barton P, Beger M, Branquinho C, Calhoun A, Caro T, Greig H, Gross J, Heino $\mathrm{J}$ et al (2015) A new framework for selecting environmental surrogates. Sci Total Environ 538:10291038. https://doi.org/10.1016/j.scitotenv.2015.08.056

Mammides C (2019) European Union's conservation efforts are taxonomically biased. Biodivers Conserv 28:1291-1296. https://doi.org/10.1007/s10531-019-01725-8

Margules CR, Pressey RL (2000) Systematic conservation planning. Nature 405:243-253. https://doi. org/10.1038/35012251

Matthews JW, Spyreas G, Endress AG (2009) Trajectories of vegetation-based indicators used to assess wetland restoration progress. Ecol Appl 19:2093-2107. https://doi.org/10.1890/08-1371.1

McAlpine C, Catterall CP, Nally RM, Lindenmayer D, Reid JL, Holl KD, Bennett AF, Runting RK, Wilson $\mathrm{K}$, Hobbs RJ et al (2016) Integrating plant- and animal- based perspectives for more effective restoration of biodiversity. Front Ecol Environ 14:37-45. https://doi.org/10.1002/16-0108.1

McDonald RI, Kareiva P, Forman RT (2008) The implications of current and future urbanization for global protected areas and biodiversity conservation. Biol Conserv 141(6):1695-1703. https://doi. org/10.1016/j.biocon.2008.04.025

Naiman RJ, Bunn SE, Nilsson C, Petts GE, Pinay G, Thompson LC (2002) Legitimizing fluvial ecosystems as users of water: an overview. Environ Manag 30:455-467. https://doi.org/10.1007/s00267-002-2734-3

Naimi B, Hamm NAS, Groen TA, Skidmore AK, Toxopeus AG (2014) Where is positional uncertainty a problem for species distribution modelling? Ecography 37:191-203. https://doi.org/10.111 1/j.1600-0587.2013.00205.x

Oksanen J, Blanchet FG, Friendly M, Kindt R, Legendre P, McGlinn D, Minchin PR, O'Hara RB, Simpson GL, Solymos P, Stevens MHH, Eduard Szoecs E, Wagner H (2018) Vegan: community ecology package. R package version 2.5-2. https://CRAN.R-project.org/package=vegan

Oliver I, Holmes A, Dangerfield JM, Gillings M, Pik AJ, Britton DR, Holley M, Montgomery ME, Raison M, Logan V et al (2004) Land systems as surrogates for biodiversity in conservation planning. Ecol Appl 14:485-503. https://doi.org/10.1890/02-5181

Ormerod SJ, Durance I, Terrier A, Swanson AM (2010) Priority wetland invertebrates as conservation surrogates. Conserv Biol 24:573-582. https://doi.org/10.1111/j.1523-1739.2009.01352.x

Palmer MA, Menninger HL, Bernhardt E (2010) River restoration, habitat heterogeneity and biodiversity: a failure of theory or practice? Freshw Biol 55:205-222. https://doi.org/10.111 1/j.1365-2427.2009.02372.x

Peel MC, Finlayson BL, McMahon TA (2007) Updated world map of the Köppen-Geiger climate classification. Hydrol Earth Syst Sci 11:1633-1644. https://doi.org/10.5194/hess-11-1633-2007

Peres-Neto PR, Jackson DA (2001) How well do multivariate data sets match? The advantages of a Procrustean superimposition approach over the Mantel test. Oecologia 129:169-178. https://doi.org/10.1007/ s004420100720

Pierobon E, Bolpagni R, Bartoli M, Viaroli P (2010) Net primary production and seasonal $\mathrm{CO}_{2}$ and $\mathrm{CH}_{4}$ fluxes in a Trapa natans L. meadow. J Limnol 69:225-234. https://doi.org/10.4081/jlimnol.2010.225

Pierson JC, Barton PS, Lane PW, Lindenmayer DB (2015) Can habitat surrogates predict the response of target species to landscape change? Biol Conserv 184:1-10. https://doi.org/10.1016/j.biocon.2014.12.017

Ramsar Bureau (2000) What is the Ramsar Convention on Wetlands? Ramsar Bureau Information Paper $\mathrm{N}^{\circ}$. 2, Gland, Switzerland

R Core Team (2018) R: a language and environment for statistical computing. R Foundation for Statistical Computing, Vienna. https://www.Rproject.org

Revelle W (2018) psych: Procedures for personality and psychological research, Northwestern University, Evanston, Illinois, USA. https://CRAN.R-project.org/package $=$ psych Version $=1.8 .12$ 
Ribaudo C, Tison-Rosebery J, Buquet D, Jan G, Jamoneau A, Abril G, Anschutz P, Bertrin V (2018) Invasive aquatic plants as ecosystem engineers in an oligo-mesotrophic shallow lake. Front Plant Sci 9:1781. https://doi.org/10.3389/fpls.2018.01781

Ricketts T, Imhoff M (2003) Biodiversity, urban areas, and agriculture: locating priority ecoregions for conservation. Conserv Ecol 8:2

Rogers K, Ralph TJ, Saintilan N (2012) The use of representative species as surrogates for wetland inundation. Wetlands 32:249-256. https://doi.org/10.1007/s13157-012-0285-9

Sánchez-Fernández D, Abellán P, Mellado A, Velasco J, Millán A (2006) Are water beetles good indicators of biodiversity in Mediterranean aquatic ecosystems? The case of the Segura river basin (SE Spain). Biodivers Conserv 15:4507-4520. https://doi.org/10.1007/s10531-005-5101-X

Schwab A, Dubois D, Fried PM, Edwards PJ (2002) Estimating the biodiversity of hay meadows in northeastern Switzerland on the basis of vegetation structure. Agric Ecosyst Environ 93:197-209. https:// doi.org/10.1016/S0167-8809(01)00347-4

Shi J, Ma K, Wang J, Zhao J, He K (2010) Vascular plant species richness on wetland remnants is determined by both area and habitat heterogeneity. Biodivers Conserv 19:1279-1295. https://doi. org/10.1007/s10531-009-9757-5

Slimani N, Sánchez-Fernández D, Guilbert E, Boumaïza M, Guareschi S, Thioulouse J (2019) Assessing potential surrogates of macroinvertebrate diversity in North-African Mediterranean aquatic ecosystems. Ecol Indic 101:324-329. https://doi.org/10.1016/j.ecolind.2019.01.017

Vandermeer J, Perfecto I (2007) The agricultural matrix and a future paradigm for conservation. Conserv Biol 21(1):274-277. https://doi.org/10.1111/j.1523-1739.2006.00582.x

Viaroli P, Soana E, Pecora S, Laini A, Naldi M, Fano EA, Nizzoli D (2018) Space and time variations of watershed $\mathrm{N}$ and $\mathrm{P}$ budgets and their relationships with reactive $\mathrm{N}$ and $\mathrm{P}$ loadings in a heavily impacted river basin (Po river, Northern Italy). Sci Total Environ 639:1574-1587. https://doi.org/10.1016/j.scito tenv.2018.05.233

Virtanen R, Ilmonen J, Paasivirta L, Muotka T (2009) Community concordance between bryophyte and insect assemblages in boreal springs: a broad-scale study in isolated habitats. Freshw Biol 54:16511662. https://doi.org/10.1111/j.1365-2427.2009.02212.x

Zacharias I, Zamparas M (2010) Mediterranean temporary ponds. A disappearing ecosystem. Biodivers Conserv 19:3827-3834. https://doi.org/10.1007/s10531-010-9933-7

Zedler JB (2003) Wetlands at your service: reducing impacts of agriculture at the watershed scale. Front Ecol Environ 1:65-72. https://doi.org/10.2307/3868032

Zellweger F, Roth T, Bugmann H, Bollmann K (2017) Beta diversity of plants, birds and butterflies is closely associated with climate and habitat structure. Glob Ecol Biogeogr 26:898-906. https://doi. org/10.1111/geb.12598

Zuur AF, Ieno EN, Walker NJ, Saveliev AA, Smith GM (2009) Mixed effects models and extensions in ecology with R. Springer, New York

Publisher's Note Springer Nature remains neutral with regard to jurisdictional claims in published maps and institutional affiliations.

\section{Affiliations}

\section{Simone Guareschi ${ }^{1,2}(\mathbb{D}) \cdot$ Alex Laini $^{3} \cdot$ Pierluigi Viaroli $^{3} \cdot$ Rossano Bolpagni $^{3,4}$}

1 Department of Ecology and Hydrology, Regional Campus of International Importance "Campus Mare Nostrum”, University of Murcia, Espinardo Campus, 30100 Murcia, Spain

2 Geography and Environment, Loughborough University, Loughborough, Leicestershire LE11 3TU, UK

3 Department of Chemistry, Life Sciences and Environmental Sustainability, University of Parma, Parco Area delle Scienze 11/a, 43124 Parma, Italy

4 Institute for Electromagnetic Sensing of the Environment, CNR, via Bassini 15, 20133 Milan, Italy 